\title{
Psychosynthesis and Culture
}

\author{
Helen Palmer
}

\author{
PSYCHOTHERAPIST, AUCKLAND
}

\begin{abstract}
This paper is a keynote address the author gave in Oslo, Norway, at a psychosynthesis conference in 2015. The conference organiser had heard Helen present at a Conference in Rome in 2012 on the development of psychosynthesis in our bicultural nation and multicultural society. He invited her to speak to 'Sensitivity and Resourcefulness in Multicultural Work'. This paper is how Helen responded to that invitation based on her experience as a psychosynthesis practitioner in Aotearoa. This paper is about how culture shapes identity as people negotiate the developmental tasks of being human. There is a tension between acknowledging that our most fundamental cultural identity is of being human, while not minimising or denying diversity and cultural difference. Shadow dynamics of power and privilege in dominant and minority group positions need to be explored. The author suggests that the psychosynthesis practice of disidentification is the key practice for managing the demands of deep cultural work. She discusses her own cultural formation as a heterosexual white woman of European ancestry raised in the Pākehā dominant culture in a bicultural context of colonialism. She invites people to engage with their own exploration. The paper tracks the development of her thinking - both from interaction with other cultures and in postmodernist thought - to examine the ontological and metaphysical assumptions the Eurocentric version of psychosynthesis makes about identity. The author concludes that disidentification helps us manage our anxious and hostile reactivity to violence and murderous 'othering' behaviour. If we aspire to increasing psychological maturity and awakening our heartfelt responsiveness we can keep finding our way with courageous compassionate action.
\end{abstract}

\section{Whakarāpopotonga}

Ko tēnei pepa te kauhau matua nā te kaituhi i kōrero i tētahi wānanga kōtuihinengaro i Ōhoro, Nōwei, 2015. I rongo te kaikōwhiri i te Wānanga i a Ērena e kōrero ana i tētahi Wānanga i Roma i te tau 2012 mō te whanaketanga o te tuinga hinengaro i roto i tō tātau motu kākanorua, hāpori matatini hoki. Nāna te pōhiri ki a ia kia tū ki te tuku kōrero mo te 'Āta Whakaarohanga me te Auahatanga i rō Mahi Kākanomaha'. Ko te pepa nei te urupare o taua tono te tūāpapa o ōna wheako kaihaumanu kōtuihinengaro i Aotearoa. Ko te kaupapa o te pepa nei ko te auahatanga a te ahurei i te tuakiri i te wā e whiriwhiri ana i ngā

Palmer, H. (2020). Psychosynthesis and Culture. Ata: Journal of Psychotherapy Aotearoa New Zealand, 24(1), 57-66. https://doi.org/10.9791/ajpanz.2020.05 
mahi whanaketanga a te tangata. He whakatetenga kei waenganui i te āheinga ko te take o tō tātau tino tuakiritanga ko tērā o te ira tangata, ā, me te kore e whakaiti e whakakāhore i te rerekētanga o te kanorau me te ahurei. E tika ana kia āta tūhurahia ngā ātarangi hikareia awe me te mana i roto i ngā rōpū whakatuanui me ngā tūranga rōpū itinga. E kī ana te kaituhi ko te ritenga kōtuihinengaro whaikore tuakiri te ritenga matua whakarite i ngā whakahau o ngā mahi ahurei hōhonu. Ka matapaki ia i tōna take ahurei i runga i tōna taeratanga wahine pākeha paiheretanga ki Ioripa i whakapakekehia i te ahurei whakatuanui o te pākehā i roto i te horopaki whakataunga whenua. E tono ana ia ki te tangata kia tū ki ā rātau ake tūhuranga. Ka whāia haerehia e te pepa te whanaketanga o ō tātau whakaarohanga - takarua mai i te mahitahi pāhekoheko ki ètahi atu ahurei, à, i roto i te momo whaiwhakaaro whakamua - ki te aromatawai i ngā whakatau ahupūngao, te tirohanga Ioripatanga kōtuihinengaro ki te tuakiritanga. E kī ana te kaituhi mā te tuku tuakiri e taea ai e tātau te whakahaere i ō tātau kaha hohenga pōhēhē kaikiri hoki me ngā whanonga kōhuru kē atu. Ki te whaia e tātau kia piki haere tonu ake te whakapakari hinengaro me te whakaoho i ō tātau urupare tarariki, ka kitea haere tonuhia e tātau tō tātau huarahi i roto i te mahi māia, te mahi ngākau aroha.

Keywords: psychosynthesis; identity; disidentification; ontological and epistemological assumptions; complex cultural work

I am honoured to be invited to speak at this Conference.

My great-grandfather Andreas Eng came from Norway, from north of Narvic. He immigrated to Aotearoa New Zealand, my homeland, in 1874 . So although this is the first time I have ever been in this land, I have ancestry that connects me to this place of mountains, sky, fjords and forests. I am also connected to this gathering through psychosynthesis. My husband Peter Hubbard and I founded the Institute of Psychosynthesis NZ in 1986. And the specific personal connection that brings me to Oslo, is that Trond invited me to come, having heard me talk in Rome in 2012 about how our cultural experience in Aotearoa has informed our thinking about psychosynthesis. ${ }^{1}$

Culture - we are immersed in culture from cradle to grave. Cultural practices shape our experience of pregnancy and birth, dying and death, and the great unfolding adventure of life in between these thresholds. And as more and more people move around the world for work, for better opportunities, or fleeing famine and war, our social world is becoming more culturally diverse. To come to agreements about how we can peacefully co-exist on the same piece of land with all our different cultural practices and ways of life is a huge challenge for us as a species. Assimilation has been a common governmental race relations policy to address this issue - the process whereby migrants are absorbed into a host culture and their cultural difference is disappeared. Integration is a more differentiated cultural policy that declares an intention that migrants from minority cultures retain their distinct identity whilst fulfilling sufficient requirements of the host culture. But the reality of 60 million refugees worldwide - half of which are children - starkly confronts us with the need to

1 Psychosynthesis is a psychospiritual psychology of Will and of Self that acknowledges the embodied patterns and sacred dimensions of human being (Palmer, 2012; 2013). 
affirm that our most essential identity is being compassionate human beings in whatever cultural environment we live.

Identity. What a key concept to bring to any conversation about culture. Cultural worldviews have a powerful yet usually unconscious impact on how we construct and organise our perceptions of belonging, connection, and identity. But whether we have grown up in a settled peaceful place where our ancestors have lived for generations, or grown up in a refugee camp and sought asylum in a foreign country, we all have had to engage in the developmental tasks of being human. Everyone develops some sense of self-identity, and needs some sense of belonging and connection with others. As we become increasingly conscious of the crises facing us and our world, we are being called to evolve our sense of who we are, to affirm that our most fundamental cultural identity is of being human, and that we need to be more conscious and responsible participants in the great web of life.

However, it is crucial that we develop our capacity to encompass different cultural identifications, rather than simplistically minimising (or even denying) cultural difference. Affirming we are all human beings must not be at the expense of acknowledging diversity. If people who belong to a dominant ethnic majority culture minimise cultural difference, how does that impact minority cultures? Also, we know human beings differentiate their sense of identity through the developmental process of distinguishing Self from Other. We need to be mindful of the tragic consequences when there is hatred of other cultures, and toxic ideologies about national identity reinforce prejudice against cultural diversity. Projection of the inferior - or superior - 'Other' compromises social justice and equity, and perpetuates social dynamics based on power and control that privilege a few at the expense of many. How do we as practitioners engage these issues? How do we develop our own genuine acceptance of the different cultural worldviews and practices we encounter? How do we distinguish between cultural difference, and oppressive practices and toxic ideologies that may be culturally rationalised?

I think our basic psychosynthesis practice of disidentifying ${ }^{2}$ is the key practice for cultural work. Disidentifying starts with the work of identifying, of understanding ourselves, our own identity. We need to build our capacity and tolerance to think and feel and embody our experience, and learn to hold a point of tension with experiences of conflict, ambivalence, and trauma. Holding a point of tension - of attention - helps us develop a felt sense of internal spaciousness in relation to the contents of our experience. This felt sense of internal spaciousness is disidentifying in action. ${ }^{3} \mathrm{I}$ want to talk about the importance of disidentification for developing a crucial cultural skill - that of accepting there are multiple cultural constructions that organise reality. This is deep cultural work, because it requires us to face into difficult feelings and profound existential challenges.

So what do I mean by "deep cultural work"? It starts with having an informed sense of your primary cultural identity - a knowing of who you are and where you come from, even if that knowledge is of trauma and survival. Then, you find out more about other cultural worldviews, and learn to accept they have as much validity as your own. It doesn't mean you

2 Assagioli's (1980) disidentification practice was: I am not my body; I am not my feelings; I am not my mind; I am a centre of pure self-consciousness and will. We say: I am more than my body/feelings/mind; I am a centre of consciousness and will, as we emphasise the inclusion of experience in the practice rather than risking a dissociated disconnection from experience, which can be identified as spiritual bypassing.

3 This assertion is not a European psychosynthesis understanding. 
have to like and agree with their values or way of life, and it certainly doesn't mean you accept oppressive power relations and toxic ideologies that may be culturally rationalised. It means you respect that there are multiple constructions and shaping of reality. This requires much more than just cognitive acknowledgement if you really wish to support cultural diversity and integration beyond the rhetoric of inclusiveness. It means becoming able to say: "I know who I am, sufficiently, and I am willing to be more than my attachment to my world view, so when I meet you I am curious and enlivened by the prospect of who you are, and I expect to be changed by the encounter and I welcome that, and I hope that in meeting me, you might also be open to being changed." 4 To be able to say this - and genuinely have the psychological spaciousness to fully engage in this encounter - means you have done a great deal of work on yourself. I want to talk about how psychologically challenging doing one's own cultural depth work can be in practice and I want to do this with reference to my own experience.

I live in a bicultural nation. Let me give you some brief historical background. Around Soo years ago the first people migrated from Polynesia and settled in these three islands near the bottom of the world. 5 They became, by right of continued occupation, the indigenous culture of Māori. Then, in the 19th century, increasing waves of British and European migrants arrived in New Zealand. At first, cultural exchanges were amicable, based on trade, but as more and more settlers poured in, grabbing land, felling forests, mining gold, bringing in diseases Māori had no resistance to, Māori were increasingly disempowered, stigmatised as savages, and traumatised. In New Zealand, a Treaty was signed in 1840 between Britain and Māori, in the hope that it would establish how these two cultures of Māori and settlers could peacefully co-exist - but the Māori version comes out of their world view and the British one out of theirs. Two very different cultural ways of organising reality.

You can guess what happened. The more powerful culture, the British Empire, colonised the indigenous culture of Mãori and marginalised Māori politically and economically. I have European ancestry. My Norwegian, English, Scottish, and French migrant ancestors were a part of this historical process of colonisation. I am a member of the dominant Pākehā majority culture, as $68 \%$ of our population of four and a half million people identify as New Zealand European. (Pākehā is a Māori word meaning a white skinned person of European descent.) Māori are $15 \%$ of the population, so they are a minority culture in their homeland. I am assuming many of you belong to the dominant majority culture of where you live. But perhaps you identify as primarily belonging to a minority culture? Whichever identification, do you have an innate sense of belonging, of roots, or do you identify more with a sense of dislocation, of not having roots? Do you identify yourself as indigenous, or is that not a word that resonates? Do you have Sami heritage? Is this an odd question? Perhaps you have mixed cultural heritage - but do similar values underpin that cultural mix?

... Back to me and my story - what am I trying to tell you by saying I live in a bicultural nation, why I introduced myself as coming from Aotearoa New Zealand, and not just as coming from New Zealand?

It's a way of showing I support the idea of bicultural partnership enshrined in the 1840 Treaty. This attitude puts me in a minority subject position in my dominant cultural group.

4 This references Robert Kegan's work and the fifth order of consciousness (Kegan, 1982,1994).

5 At this point in the keynote address, the author displayed the world map on a Powerpoint background, with the Pacific in the centre. The Norwegian audience had never seen that visual world perspective. 
I grew up in New Zealand under the ideology that "we are all New Zealanders", which was the governmental race relations policy at the time of integration through assimilation. I had no idea of the consistent marginalisation Māori people experienced in so many ways, until I went to university and met radical Māori activists. I began to understand, because at the same time I was getting into feminism, that how the world is organised is a contestable reality. As a young woman, I was more focused on the identity issues of power, gender, and sexual orientation emerging in Western culture, than the historical trauma analysis being developed by colonised indigenous cultures around the world. I had a sense of injustice as I encountered more and more discrimination against women. It made me angry. These feelings helped me start recognising other forms of injustice and oppressive practices, and to think about what happens when a dominant narrative of assimilation is imposed on everyone, silencing alternative stories, disappearing other realities, banishing minorities to the margins and the ghettoes.

And as I am talking, I notice it is still easier to position myself in an empathic alliance with Māori marginalisation and oppression, than be with my internal discomfort about carrying more power and privilege simply by being a member of a white majority culture. I notice an internal commentary along the lines of: "my ancestors were working class, they weren't wealthy, privileged people. They didn't do the really bad things ... I'm not racially prejudiced against Māori ... I am supportive of Māori women ... I don't have as much power as a white man ...” Yes, and ... it is important I don't let my discomfort take me into defensive denial of the cultural fact that I was brought up within the dominant story of my ethnic group. This lens shaped my view of the world. I didn't initially learn about life from a marginalised cultural perspective. I needed to develop my empathy for others with a different cultural identity formation and understand there are differences than cannot be denied, disappeared, or assimilated under the rubric of "we are all one".

So, not denying, nor drowning in white liberal guilt, or romanticising and idealising indigenous and marginalised cultures, because these are other common reactions people in dominant majority subject positions can have. This is doing a difficult piece of cultural work. It's about identifying how much power and privilege you carry from your cultural heritage in terms of dominant and minority subject positions, in whatever cultural context you live. These positions are complex and nuanced. For example, sexuality and gender inform identity and a sense of self in the world. The different cultural constructions of sexuality and gender have a huge impact on the degree of structural power and privilege you will be accorded and that you will assume. Who you are requires paying attention to gendered power relations playing out within your unique cultural context. Some of my cultural identity story is of being a heterosexual white woman of European ancestry raised in the Pākehā dominant culture in a bicultural context of colonisation: what are your stories?

Peter and I left New Zealand in the 1970 s as young adults, and returned home to found the Institute of Psychosynthesis NZ in 1986. An important part of establishing the Institute was to deepen our sense of belonging and connection with our new professional therapeutic community. We joined the New Zealand Association of Psychotherapists in 1991. The Association was beginning to explore what being bicultural, and a Treaty partner, actually meant. We realised this exploration was necessary for the Institute. What could psychosynthesis, with its cultural ancestry of psychoanalysis, Western 'depth' psychology, 
Eastern 'height' psychology, and North American transpersonal psychology, contribute to bicultural partnership? What was this process, what were the conversations, particularly as Aotearoa was becoming more multicultural?

During our training at the London Institute, Peter and I had been significantly influenced by Father Micael O'Regan's (1984) thinking about disidentification. Micael was the founder of Eckhart House in Dublin, Ireland, and I assisted him to run the first Irish Foundation Year in $1981 / 1982$. He asserted that "I" is distinct from, rather than separate from, body, and suggested using the statement "I am more than my body" rather than "I am not my body". From the stimulation of working with Micael, we made the philosophical commitment to use this version of the disidentification practice: "I am more than my body (and my feelings and my mind)." This way of thinking about human identity resonates with Māori perceptions of the interconnected wholeness of the immanent and transcendent dimensions of life.

So, as we found points of connection and similarity with Mãori, such as the emphasis placed on spirituality for a holistic understanding of human beings, we were also learning about how different our experience as Pākehā was from theirs. We learned more about the effects of historical trauma, as Māori challenged the endemic practices and pressures of assimilation, particularly in the areas of education, health, and justice. We became sensitised to the importance of cultural frameworks on the formation of identity, and the need for us as educators to be inclusive of Māori psychological knowledge and the specific cultural needs of our Māori and Pasifika students. If we had ignored these crucial cultural issues we would have been a Pākehā training institute perpetuating the dominant cultural story of identity. Integrity required a more nuanced exploration.

"Who am I?" is a profound existential question, going to the heart of identity. Assagioli ${ }^{6}$ explores identity with the method of starting from within, of beginning with the self of the individual, with his or her presence. He believed this search for self-identity involves experiencing a true, phenomenological inner reality of pure self-consciousness, so he includes the spiritual dimension in his conception of personal identity. Although he states psychosynthesis does not aim nor attempt to give a metaphysical nor a theological explanation of the Mystery, clearly he is aligned with spiritual traditions that teach that the nature of our fundamental identity is an eternal transcendent reality not located in any of the temporary, mutable states of existence, nor in the landscape, the place, the materiality of our earth.

If you construct identity in this way, and have a spiritual practice informed by this ontological view of reality, notice how you feel as I suggest these ideas are culturally determined, and not just "how things are". There are other worldviews that constellate identity differently. For instance, Māori conceive of identity as intrinsically linked with the natural world. Place and person are not separate; identity is ecologically contextualised. A Māori ritual of greeting will begin with a person saying who their mountain is, who their river is (not "what" their mountain or river is, "who") and who their ancestors are, before speaking their own name. There is a Native American phrase that says this beautifully: "All my relations". This construction of identity affirms we are all participating in the act of

6 Dr. Roberto Assagioli, the founder of psychosynthesis, submitted his doctoral thesis critiquing psychoanalysis in 1910. He thought that optimal psychological health required an exploration of existential and spiritual dimensions of life as well as a focus on the personal past as in psychoanalysis. (See, for example, Assagioli, 1980; 1984.) 
Creation, in the evolution of the Universe, and that we are connected with all life. Identity is located in both immanent and transcendent realms.

Back home in Aotearoa, the years went by for us. We learned more about our similarities and differences with other psychotherapeutic modalities, and we learned more about other cultures, particularly Māori culture. We realised we weren't just learning what these diverse bodies of knowledge said about the world and the nature of reality, we were being called to a deeper paradigm enquiry into what we know and how we know it. The fundamental process of meaning-making itself could be explored. This is a profound disidentification.

I had started training in 1979 with the London Institute when I was 27. I was immersed in psychosynthesis. We had founded the Institute of Psychosynthesis NZ. But we realised we needed to disidentify from psychosynthesis itself as a body of knowledge. It is an extraordinarily inclusive and comprehensive psychology. However, if we didn't have the courage to consciously examine its underpinning assumptions, its cultural worldview, we would be caught in its construction of reality. We had already risked being different by not teaching the orthodox practice of disidentification. But what might happen if we questioned the ontological and epistemological foundations of what we were teaching? It helped us dare to undertake this process by thinking of it as a postmodern enterprise.

I am using the term postmodern as part of an unfolding cultural vision that suggests human knowledge is subjectively and locally determined, cannot be fully objectively known, and that reality is not a solid, self-contained 'given' but rather, is participatory, indeterminate and multidimensional. It challenges the assumptions underpinning the modernist approach to knowledge that reality can be objectively known, because a modernist frame suggests there are sovereign and enduring truths that can be apprehended through reason alone. Postmodernism, as an epistemological stance applicable to any knowledge domain of contemporary culture, supports a view of culture as a dynamic, fluid and contested process. This view acknowledges the nuances and complexities arising from intergenerational change, intermarriage, transnational mobility, and the consequent hybrid multiple identities, belongings and dislocations of contemporary life. This process view makes thinking about culture more flexible. It helps us consider different perspectives, conflicting ideas, and new possibilities.

Psychologically, it requires being willing to be uncertain, and open to reality as change itself. There are multiple views; reality is complex. It's hard to tolerate the visceral anxiety of not knowing everything, of reality itself being in flux, and one common reaction people have to living with uncertainty and anxiety about the future is to look for certainty and rules. Complexity gets simplified and reduced to dualities of defensive splitting: black and white; goodies and baddies, us and them. This is intensified when survival is at issue, when access to resources is compromised, as we can see from the reactions to the current refugee crisis. Disidentifying, stepping back and compassionately making space around defensive dualities; tolerating being confused, uncertain, reactive and scared; are essential skills to be well resourced for cultural work. This is really difficult to do if you haven't practiced letting go of the certainties that your own cultural worldview has given you, nor examined your assumptions about power and privilege.

Cultural sensitivity requires us to be vigilant about how we exercise power, and one of the greatest power practices is how respectful we are about knowledge. If we only pay 
attention to the dominant stories of how things are and how we should be, or only to the narratives that reinforce our own worldview, we don't have the necessary cultural humility that paradoxically helps us develop an inclusive and sophisticated cultural confidence that is heart-centred.

I believe psychosynthesis, with its practice of disidentification, its clear focus on will and consciousness, and commitment to a healing vision of interconnected wholeness and synthesis, has much psychospiritual wisdom to offer people from any cultural background. But how we teach psychosynthesis in Aotearoa needed updating for our cultural setting, so it is not constrained and limited by its hidden Eurocentric and metaphysical assumptions about identity and the nature of reality, nor by modernist language that reifies conceptual entities and makes it harder to talk about process.

Another challenge to our practice of disidentifying is dealing with all that gets triggered in us by the growing threat of extremist violence - some of which (not all) is positioned as a religious attack on Western culture. Scott Atran (2010) is an anthropologist who has interviewed many young people who have joined extremist Islamic terrorist movements. He considers Al Qaeda, ISIS and related groups pose the greatest threat as the world's most dynamic global countercultural movement, as they offer young people in the vulnerable transitional stages of life a sense of meaning and purpose. He says that youth need something to make them dream, to engage in a life of significance through struggle and sacrifice in comradeship. Vulnerable young people who don't feel they belong in their host cultures (who look and sound different from the dominant ethnic majority, are often unemployed, and socially powerless) are actively enlisted and financially supported by powerful men willing to use violence to spread a toxic version of the ideology of Wahhabism. The extremism of jihad offers certainties of identity, belief and belonging, and a sense of a sacred cause. How do we counter this threat?

Youth need a positive personal dream, with a concrete chance of realisation. They need a chance to create their own local initiatives. There is another growing countercultural movement that calls everyone to participate in meaningful activities - and this is the ecological awareness that we are profoundly connected with all that there is. Any fighting needs to be as fierce warriors for social justice, for the generations to come in whichever cultural milieu they live, for the Earth and all beings. This countercultural movement holds a worldview of interconnected wholeness, with which psychosynthesis aligns. This worldview is not supported by the dominant positivist capitalist techno-rational worldview of globalisation, but it is a significant activation of spiritual, ecological and political consciousness emerging worldwide. I consider that this is the most dynamic global countercultural movement.7

Our work makes a vital contribution to this movement by helping people become more psychologically mature, able to engage complexity, tolerate and manage anxiety and defensive reactions, and to make compassionate wise choices.

The practice of disidentifying helps us align with the vision of interconnected wholeness and to act courageously. This vision can encompass the reality of violence, whereas violence cannot encompass wholeness. This vision can acknowledge the experiences of violence,

7 Since presenting this keynote speech, the emergence of Extinction Rebellion and the global work of several young climate activists evidences this as a countercultural movement of huge significance. 
despair, hatred, and suffering that overwhelm us from time to time, and, it can keep calling us to be more compassionate, powerful and loving human beings.

I could not end this talk without acknowledging that on 22 July, 2011 here in Oslo, Anders Breivik massacred 77 people. Maybe some of you knew someone, or more than one person, whom he killed or injured. Everyone in this room has been affected by this one man's violence, and I express my deep sympathy to you. I acknowledge their deaths, and your loss, and the continuing traumatic impact of his extremist act of terror. I also acknowledge the shock upon shock experienced not just by Norwegians, but also by the world, that an ethnic Norwegian committed this atrocity, not an ISIS terrorist, and he was killing fellow Norwegians. How could this happen?

He was assessed as being narcissistic. When we look closely at his story, his ancestry, we can hypothesise about how much intergenerational trauma he was carrying from his mother and her history that we might frame as a more borderline aetiology of rage. A narcissistic absent father, a borderline mother. What a toxic heritage, what a tragic story. We need to disidentify from our reactions and think about the aetiologies of traumatic rage and narcissism that fuel those who feel entitled to terrorise and murder other human beings to assert their distorted view of how society should be organised. These powerful energies are part of our human psychology. But we can choose not to act in ways that harm others. At the funeral service in Oslo Cathedral three days after the massacre, Jens Stoltenberg said "Our response is more democracy, more openness, more humanity. But never naïveté" (as cited in Orange, 2012). ${ }^{8}$ Last month, four years on, the AUF Youth Camp returned to Utoya. Emilie Bersaas, a survivor who returned, said: "It's a naïve thing to say, but we want to change the world, and we're young, that's why we become members. It's the values we stand for, and our ideology really needs to be defended: we need to work for it" (in Ridley, 2015).

All these words act as beacons of hope. They point to how we can use the practice of disidentification to activate powerful responses to violence that show a way forward of transformational healing, rather than reactive retaliation. Wherever we are located culturally, we have to resist the urge to demonise those who harm others; otherwise we end up hating the haters. To hold onto our humanity, we have to find a way to hold onto the humanity of oppressors, even as we hate their behaviour. Disidentifying helps us create spaciousness in our beings, so we don't get trapped in the same dehumanising 'Othering' dynamics by which terrorists rationalise their actions. Making space helps us contain our reactions, helps our thinking be clear, and supports us aligning with what we hold highest and best - that process ofaligning so central to Assagioli's founding vision of psychosynthesis. This is true psychological maturity, necessary for human beings in any culture. Great courage and commitment are needed to keep opening our hearts. We would be extremely naïve to say this is easy. It is nevertheless essential. Whatever the future holds, if we individually choose to act in accordance with our values, we reveal the heart of humanity, in sacred service for all beings.

8 The 2019 massacre in Christchurch demonstrates how relevant a Prime Minister's words can be. However, "This is not us" quickly became "This has been us. And we don't want this to be us." 


\section{PSYChosynthesis AND CULTURE}

\section{References}

Assagioli, R. (1980). Psychosynthesis: A manual of principles and techniques. Wellingborough,

Northamptonshire, UK: Turnstone Books.

Assagioli, R. (1984). The act of will. Wellingborough, Northamptonshire, UK: Turnstone Books.

Atran, S. (2010). Talking to the enemy. London, UK: Penguin.

Kegan, R. (1982). The evolving self. Cambridge, MA: Harvard University Press.

Kegan, R. (1994). In over our heads. Cambridge, MA: Harvard University Press.

O’Regan, M. (1984). Reflections on the art of disidentification. Institute of Psychosynthesis

Yearbook, IV, 44-48.

Orange, R. (2012, April 15). 'Answer hatred with love': How Norway tried to cope with the horror of Anders Breivik. The Guardian. https://www.theguardian.com/world/2012/apr/15/andersbreivik-norway-copes-horror

Palmer, H. (2012). Psychosynthesis in the South Pacific: Ontological and epistemological considerations in the context of Aotearoa New Zealand, Psychosynthesis monograph 10. London, UK: Institute of Psychosynthesis.

Palmer, H. (2013). Psychosynthesis in the South Pacific. In S. Simpson \& R. Evans, (Eds.), Essays on the theory and practice of a psychospiritual psychology. London, UK: Institute of Psychosynthesis.

Ridley, L. (2015, August 8). Utoya island summer camp returns to the island four years after Anders Breivik massacre. Huffington Post. https://www.huffingtonpost.co.uk/2015/o8/o8/ utoya-island-norway-anders-breivik-massacre-killings-emilie-bersaas-auf_n_7954998.html

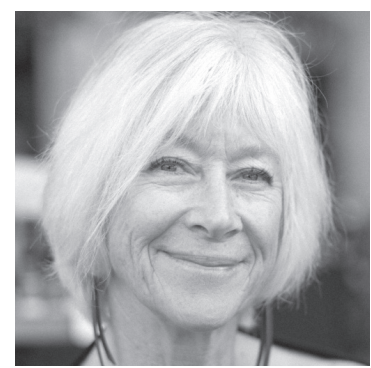

Helen Palmer has a background in education. After some years in the UK she trained in psychosynthesis, and co-founded the Institute of Psychosynthesis NZ with her husband Peter Hubbard on their return to Aotearoa in 1986. The Institute closed in December 2018, after 32 years of offering psychosynthesis for self-development, as well as professional training for counsellors and psychotherapists. During this time she also completed a law degree, became an ordained Interfaith minister and marriage celebrant, and then wrote a thesis on Psychosynthesis in the South Pacific (awarded with Distinction) from Middlesex. Helen and Peter's commitment to developing a psychotherapeutic understanding that is respectful of Māori cosmology and identity was deeply supported by their growing relationship with Joe Turner, who became the Institute's kaumatua in 1996 until his death in 2014. Helen has been a member of NZAP since 1991, is a registered psychotherapist, and a Fellow of PAnzA. She is a current member of the Health Disciplinary Tribunal. She is a Director of Psychosynthesis Education and Research. She has a private practice as a psychotherapist and as a supervisor. She is interested in the intergenerational transmission of resilience as well as trauma, which began when working with many cultural backgrounds in London. She is also following the emerging conversations about gender, identity and sexuality. 